\title{
Anatomical differences in three wing muscles of the Grey heron (Ardea cinerea), the Common buzzard (Buteo buteo) and the Common kestrel (Falco tinnunculus): a possible functional interpretation
}

\author{
Marco Canova ${ }^{1 *}$, Carla Bedoni ${ }^{2}$, Valeria Harper $^{2}$, Anna Maria Barazzoni ${ }^{1}$, \\ Adriano de Faveri ${ }^{3}$, Annamaria Grandis ${ }^{1}$
}

\begin{abstract}
In this paper, a description of the coracobrachialis caudalis, the scapulotriceps and the extensor carpi radialis muscles is presented in three different species (Common kestrel, Common buzzard and Grey heron) that exhibit notably differing flight styles. The primary goal of this research is to describe the gross anatomy of species not previously examined. Secondly, we attempt to advance a functional interpretation of the structures studied, to understand if such noticeable differences in flight style could have induced a differentiation in the above mentioned wing muscles. Regarding the coracobrachialis caudalis muscle, the Grey heron exhibited an unusual conformation with two "reversed" heads and a great amount of fibrous bundles. Moreover, the "anchors" of the scapulotriceps muscle were well developed in the Grey heron and vestigial in the Common kestrel, while an intermediate situation was observed in the Common buzzard. In addition, the extensor carpi radialis muscle showed interesting findings concerning the number of heads and their disposition. Our data may corroborate some previously advanced functional interpretation. In particular, the structure of the coracobrachialis muscle is in line with the hypothesis of its role as muscular strut. Moreover, the humeral and scapular anchors could play a role in increasing the scapulotriceps tension during some phases of the beat cycle or it may be involved in maintaining wing posture. Regarding the different number of heads and the disposition of the extensor carpi radialis muscle, we believe that it could play a role in maintaining the wing position. Although a correct functional interpretation can be obtained only through multidisciplinary studies, we believe that an in-depth gross anatomy study should always be conducted beforehand, to serve as basis for further and more specific research.
\end{abstract}

Key words: Avian anatomy, arm, forearm, myology, shoulder, wild birds, wing.

Riassunto - Anatomical differences in three wing muscles of the Grey heron (Ardea cinerea), the Common buzzard (Buteo buteo) and the Common kestrel (Falco tinnunculus): a possible functional interpretation.

\footnotetext{
Department of Veterinary Medical Sciences, University of Bologna - Via Tolara di Sopra 50, 40064 Ozzano dell'Emilia (BO) Italia.

${ }^{2}$ Veterinary practitioner - Italia.

${ }^{3}$ Institute for Environmental Protection and Research (ISPRA) Via Ca' Fornacetta 9, 40064 Ozzano dell'Emilia (BO) Italia.

*Corresponding author: marco.canova4@unibo.it

(C) 2015 Marco Canova, Carla Bedoni, Valeria Harper, Anna Maria Barazzoni, Adriano de Faveri, Annamaria Grandis
}

Received: September 5, 2014

Accepted for publication: January 17, 2015
Il presente studio intende fornire una descrizione dei muscoli coracobrachiale caudale, scapolotricipite ed estensore radiale del carpo in tre specie di uccelli che presentano tipologie di volo differenti. La comprensione della funzione dei muscoli negli uccelli è tutt'ora un obbiettivo per i ricercatori. La maggior parte degli studi funzionali viene attualmente effettuata utilizzando gallerie del vento ed apparecchiature per l'elettromiografia congiuntamente a studi di istochimica ed immunoistochimica per la tipizzazione delle fibre muscolari. Attualmente non vi è certezza circa l'esatta funzione di alcuni muscoli dell'ala ma interessanti ipotesi sono state avanzate da alcuni autori (Dial et al., 1991; Dial 1992a, 1992b; Meyers 1992a, 1992b, 1993, 1997; Meyers \& Mathias 1997; Wooley, 2000; Meyers \& Stakebake, 2005; Corvidae et al., 2006; Maxwell \& Larsson, 2007). Per quanto riguarda il muscolo coracobrachiale caudale, si pensa possa agire sia da depressore dell'omero che da stabilizzatore della spalla, contrastando la iperotazione di quest'osso (Dial et al., 1991; Meyers 1992a; Wooley, 2000). Il muscolo scapolotricipite si ritiene invece possa estendere e stabilizzare il gomito (Dial et al., 1991; Dial 1992a, 1992b; Meyers 1992a, 1993, 1997; Robertson, 2012). Per quanto concerne il muscolo estensore radiale del carpo, invece, Meyers (1996) ipotizza possa estendere la mano e coadiuvare la flessione dell'avambraccio, mentre secondo Dial (1992a) stabilizzerebbe ed estenderebbe il polso. Sempre Meyers (1997) ritiene che possa avere un ruolo posturale e mantenere il polso esteso. Durante il presente studio, sono stati esaminati soggetti di Airone cenerino, Poiana eurasiatica e Gheppio comune. L'Airone cenerino è un migratore regolare, dispersivo ed estivante con movimenti autunnali e primaverili. Il suo volo è caratterizzato da lente battute effettuate mantenendo le ali arcuate e le primarie esterne ben evidenti. Quando invece atterra sul nido o in zone di alimentazione caratterizzate da spazi limitati, si dimostra alquanto agile attuando scivolate laterali e atterraggi quasi verticali, spesso effettuati mantenendo ali e testa estese. La Poiana eurasiatica è un migratore invernale ma anche sedentario in Italia. In volo mantiene le ali piatte e leggermente innalzate, spesso con il polso piegato. Esegue scivolate e cerchi discendenti alternati ad ampi e lenti battiti d'ala. Durante la caccia può rimanere posata o coprire in volo ampie aree in cerca di prede a terra. Il Gheppio comune è anch'esso un migratore invernale ma può essere anche sedentario in Italia. Esegue un volo attivo caratterizzato da una serie di battute inframezzate a frequenti planate ed attua un battito meno potente rispetto ad altri falchi. Durante la caccia si sospende ad altezze moderate al di sopra del terreno, abbassandosi ogni tanto per poi tornare a volare a punto fisso per mezzo di rapidi colpi d'ala a coda aperta. Lo scopo principale della presente ricerca è stato descrivere l'anatomia macroscopica di specie non precedentemente esaminate e, secondariamente, formulare ipotesi funzionali legate alle particolarità emerse al fine di correlare le differenze nella tipologia di volo alla differenziazione delle strutture esaminate. Per quanto concerne il muscolo coracobrachiale caudale, questo si presenta variamente conformato all'interno delle specie esaminate. L'Airone cenerino esibisce, infatti, un muscolo composto da due ventri intimamente associati in cui il capo mediale origina per mezzo di fibre carnose, mentre quello laterale tramite un ben sviluppato tendine. Il capo mediale presenta un'inserzione prossimale a livello di un'area compresa tra l'estremità sternale e la metà caudale della superficie ventrale del coracoide, late- 
ralmente all'inserzione prossimale del muscolo sopracoracoideo. Il capo laterale trae origine invece dal processo laterale del coracoide, lateralmente all'inserzione del legamento sternocoracoideo laterale. Tra il terzo caudale e la metà dell'intero muscolo, dal tendine del capo laterale, si sviluppa un ventre carnoso fusiforme che termina assieme al capo mediale. Nella Poiana eurasiatica è possibile osservare un muscolo bipennato che origina per mezzo di fibre carnose dall'incisura laterale dello sterno e dal corpo del coracoide, in intima associazione con il muscolo sopracoracoideo. Nel Gheppio comune questo muscolo origina sia dall'incisura laterale dello sterno che dai segmenti sternali delle prime tre coste vere, dalla faccia muscolare dello sterno e dai due terzi caudali di entrambe le facce del corpo del coracoide. L'inserzione sternale sovrasta e ricopre totalmente il muscolo sternocoracoideo. Il ventre muscolare è composto da due ventri asimmetrici delineati da una lieve depressione. Il capo mediale è quasi completamente composto da fibre carnose, mentre il capo laterale mostra una componente fibrosa, sia superficialmente che sul margine laterale. Distalmente si assiste ad un incremento della componente fibrosa che si organizza progressivamente nel tendine terminale. In tutte le specie esaminate, $\mathrm{i}$ due capi terminano convergendo sul tubercolo ventrale dell'omero, caudalmente all'inserzione dei muscoli sottoscapolare e sottocoracoideo. Per quanto concerne il muscolo scapolotricipite, questo mostra una conformazione abbastanza costante nelle specie esaminate. Fanno eccezione i lacerti fibrosi scapolare ed omerale che esibiscono, invece, un diverso sviluppo. Queste strutture si presentano, infatti, molto sviluppate nell'Airone cenerino e vestigiali nel Gheppio comune, mentre la Poiana eurasiatica mostra uno sviluppo intermedio. Anche il muscolo estensore radiale del carpo ha evidenziato una discreta variabilità tra le specie oggetto di studio. Infatti, pur originando sempre dal tubercolo sopracondilare dorsale dell'omero e terminando a livello del processo estensore del carpometacarpo, ha mostrato interessanti evidenze riguardo al diverso numero di capi. Difatti, nell'Airone cenerino e nel Gheppio comune questo muscolo risulta composto da un capo dorsale e da uno ventrale, mentre la Poiana eurasiatica presenta un muscolo composto da tre capi distinti. Caratteristica è anche l'origine nell'Airone cenerino, dove i due tendini si incrociano a formare una $\mathrm{X}$, mentre nelle altre specie risultano sovrapposti in senso dorsoventrale. Si ritiene che i dati emersi dal presente studio possano supportare alcune ipotesi funzionali avanzate in precedenza. Nello specifico, la conformazione del muscolo coracobrachiale caudale è riconducibile ad un suo possibile ruolo nella stabilizzazione dell'omero, così come già suggerito da altri autori (Wooley 2000). Infatti, un precedente studio (Wooley 2000), ha evidenziato come sia la disposizione che la tipologia di fibre di questo muscolo, potrebbero permettergli di effettuare rapide regolazioni del beccheggio durante la fase di abbassamento dell'ala evitando l'iperotazione dell'omero. Si può pertanto supporre che la particolare conformazione di questo muscolo nell'Airone cenerino, congiuntamente all'alta percentuale di fibre collagene, possano rappresentare un adattamento funzionale. Questa specie infatti possiede ali ampie ed attua, soprattutto in atterraggio, battiti d'ala frequenti che indubbiamente generano un forte attrito ed una tendenza dell'ala a ruotare sul piano longitudinale. L'azione di stabilizzazione della spalla e la capacità di opporsi alla rotazione dell'omero del muscolo coracobrachiale caudale potrebbero quindi garantire il mantenimento dell'angolo di attacco dell'ala massimizzando le prestazioni in caso di atterraggi pesanti. Non di meno, il lacerto fibroso scapolare e quello omerale, in virtù dei leveraggi che instaurano, potrebbero giocare un ruolo nell'aumentare la tensione del muscolo scapolotricipite durante alcune fasi del battito dell'ala o addirittura rivestire un ruolo posturale. La maggiore tensione del muscolo potrebbe stabilizzare il gomito, riducendo il rischio di lussazione di questa articolazione, specialmente durante l'atterraggio o il decollo. Per quanto riguarda le differenze nel numero di capi del muscolo estensore radiale del carpo e la loro differente disposizione, si reputa possa essere legata al mantenimento della postura alare. Nondimeno, la presenza di tre capi nella Poiana eurasiatica rappresenta una caratteristica non precedentemente riportata in letteratura. Ancora, nonostante sia già stata riscontrata durante precedenti studi la presenza di due capi affiancati nei Ciconiiformes (Vanden Berge 1970 and Meyers 1997), questi erano apparsi disposti in maniera discordante. Difatti Meyers (1997; Fig. 3) illustra il capo dorsale del muscolo coracobrachiale caudale come il più vicino al radio. La disposizione da noi riscontrata nell'Airone cenerino, invece, corrisponde a quella prospettata da Vanden Berge (1970) con il capo ventrale più prossimo al radio. A fronte di quanto fin qui esposto, nonostante una corretta interpretazione funzionale di un muscolo possa essere ottenuta solamente per mezzo di studi multidisciplinari, si ritiene che un approfondito studio dell'anatomia macroscopica debba essere sempre preventivamente condotto, al fine di fornire conoscenze di base per future e più specifiche ricerche.

Parole chiave: Avian anatomy, arm, forearm, myology, shoulder, wild birds, wing.

\section{INTRODUCTION}

Over the last several years, our research group has been conducting an in-depth study of wing muscles in many wild birds with different flight capabilities. Some fascinating anatomical differences have drawn our attention. In particular, this work examines the differences observed in the coracobrachialis caudalis, the scapulotriceps and the extensor carpi radialis muscles of the Grey heron (Ardea cinerea L., 1758), the Common buzzard (Buteo buteo L., 1758) and the Common kestrel (Falco tinnunculus L., 1758). These species exhibit notably differing flight styles and habits. The Grey heron is a regular autumn and spring migrant and also dispersive (Brichetti \& Fracasso, 2003). Its flight action is slow, with pronounced flaps of noticeably bowed wings. But when, for example, descending to the nest site or confined feeding area, flight action is markedly agile, side-slipping and parachuting downwards, often with head and legs extended (Cramp, 2004). The Eurasian buzzard is a migrant wintering, but also sedentary in Italy (Brichetti \& Fracasso, 2003). During soaring, it maintains its wings flattish and slightly lifted, often with the wrist kinked. It displays stoop and loops in descending and undulating flight alternating with high and slow wing beats. The Eurasian buzzard sits mostly hidden on low perches when hunting, while it is frequently seen on the wing, covering huge areas while looking for hunting grounds (Forsman, 2003). The Common kestrel is usually a migrant wintering but can also be sedentary in Italy (Brichetti \& Fracasso, 2003). Its flapping flight consists of a series of wing-beats interrupted by frequent glides and the wing action is looser than in other falcons. When hunting it quarters at moderate height above the ground, stooping every now and then to hover against the wind with fluttering wing-beats and fanned tail (Forsman, 2003). Understanding the function of muscles in birds is currently a challenge for researchers. Functional studies on bird muscles are performed using wind tunnel and electromyographic apparatus as well histochemistry and immunohistochemistry to characterize fiber types. To date there is uncertainty about the exact function of some muscles, but nevertheless interesting hypotheses have been advanced (Dial et al., 1991; Dial 1992a, 1992b; Meyers 1992a, 1992b, 1993, 1997; Meyers \& Mathias 1997; Wooley, 2000; Meyers \& Stakebake, 2005; Corvidae et al., 2006; Maxwell \& Larsson, 2007). Concerning the $m$. coracobrachialis caudalis, it may act as a humerus depressor and also as a shoulder stabilizer, reducing the hyper-rotation of the same bone (Dial et al., 1991; Meyers 1992a; Wooley, 2000). M. scapulotriceps 
may, instead, act as an extensor of the elbow, but also as an elbow joint stabilizer (Dial et al., 1991; Dial 1992a, 1992b; Meyers 1992a, 1993, 1997; Robertson, 2012). Regarding the $m$. extensor carpi radialis; it may extend the manus and assist forearm flexion (Meyers, 1996) or stabilize and extend the wrist (Dial 1992a). Meyers (1997) also hypothesized a posture role of this muscle in maintaining the extended wrist. The goal of this study it to provide a description of the anatomical differences observed in the muscles described of the examined species. We also hypothesize a functional interpretation of the examined structures, attempting to correlate muscle differentiation with the flight style of the species investigated.

\section{METHODS}

Anatomic material for dissection was obtained from the "Centro di recupero degli animali selvatici" della "Lega Italiana Protezione Uccelli" (LIPU) of Padova and from the "Ufficio Faunistico del Servizio Foreste e Fauna" of the "Guardia Forestale" of the "Provincia Au- tonoma" of Trento. For each species we examined three deceased subjects. The animals, which had died due to various causes, were transferred and maintained in cold storage $\left(\right.$ at $\left.-20^{\circ} \mathrm{C}\right)$ until the moment of dissection. Chicks, juvenile subjects and animals that had suspected or evident injuries to the thoracic limbs were excluded from the study. The remaining birds were then bilaterally dissected from the shoulder to the hand, effecting a progressive exposition of the muscle layers (Fig. 1). The anatomical nomenclature is from Nomina Anatomica Avium (Baumel et al., 1993). Photos were taken with a Finepix HS 50 Fuji camera. The images were then digitally elaborated using Adobe Photoshop CS4.

\section{RESULTS}

\section{Musculus coracobrachialis caudalis (CBCa)}

In the Grey heron, the $\mathrm{CBCa}$ is a well-developed muscle composed of two intimately associated parts (Fig. 2A). The medial head arises by fleshy fibers from an area between the sternal extremity and the caudal
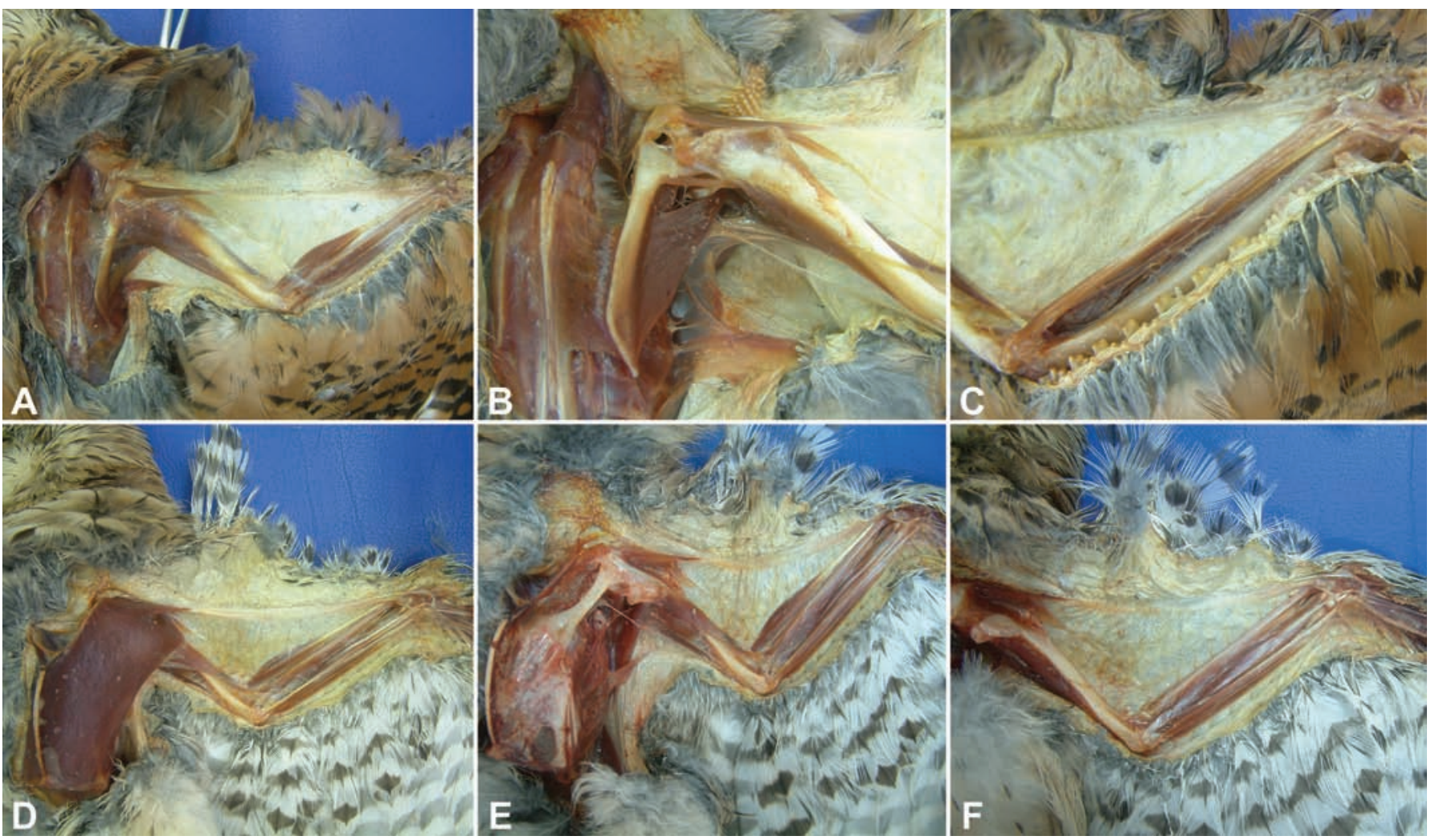

Fig 1 - Right (A-C) and left wing (D-F) of the Common kestrel. Stepwise dissection of the muscle layers of the dorsal (A-C) and the ventral (D-F) aspects. In B, the mm. romboideus superficialis, latissimus dorsi, major and minor parts of $m$. deltoideus and scapulotriceps have been removed. In C the ECR, the terminal tendon of the caudal head of the propatagial part of the $m$. deltoideus and the mm. extensor digitorum communis, supinator, ectepicondilo-ulnaris and extensor carpi ulnaris have been removed. In E the mm. pectoralis, supracoracoideus, coracobrachialis cranialis and caudalis have been removed. In $\mathrm{F}$ the $\mathrm{mm}$. coracobrachialis cranialis and caudalis, scapulotriceps, biceps brachii and the ECR have been removed. / Ala destra (A-C) e sinistra (D-F) di Gheppio comune. Dissezione stratigrafica dei muscoli della faccia dorsale (A-C) e ventrale (D-F). Nella figura B i muscoli romboideo superficiale, grande dorsale, le parti minore e maggiore del muscolo deltoide ed il muscolo scapolotricipite sono stati asportati. In C il muscolo estensore radiale del carpo, il tendine terminale del capo caudale della parte propatagiale del muscolo deltoide ed i muscoli estensore digitale comune, supinatore, ectepicondilo-ulnare ed estensore ulnare del carpo sono stati asportati. In E i muscoli pettorale, sopracoracoideo, coracobrachiale craniale e caudale sono stati rimossi. In F i muscoli coracobrachiale craniale e caudale, scapolotricipite, bicipite brachiale e estensore radiale del carpo sono stati asportati. 


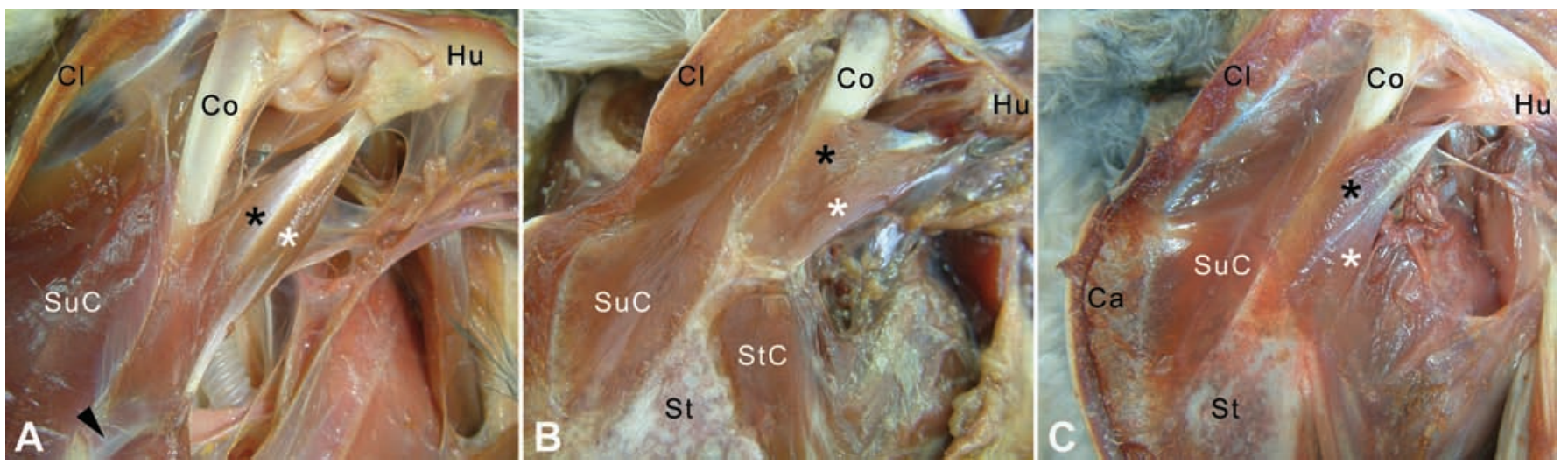

Fig. 2 - Ventral view of the left shoulder of the Grey heron (A), Common buzzard (B), Common kestrel (C). The white asterisk indicates the lateral head of the $\mathrm{CBCa}$, while the black asterisk points at the medial head. Ca: sternal keel; Co: coracoid; $\mathrm{Cl}$ : clavicula; Hu: humerus; St: sternum; StC: m. sternocoracoideus; SuC: m. supracoracoideus. In (A) the arrowhead indicates the Lig. sternocoraeoideum laterale. / Veduta ventrale della spalla sinistra di Airone cenerino (A), Poiana eurasiatica (B) e Gheppio comune (C). L'asterisco bianco indica il capo laterale del muscolo coracobrachiale caudale, mentre l'asterisco nero evidenzia il capo mediale. Ca: carena dello sterno; Co: coracoide; Cl: clavicola; Hu: omero; St: sterno; StC: muscolo sternocoracoideo; SuC: muscolo sopracoracoideo; In (A) le teste di freccia evidenziano il legamento sternocoracoideo laterale.

middle of the ventral aspect of the coracoid, laterally to the proximal insertion of the $m$. supracoracoideus. At the level of the medial margin of the coracoid, a fibrous bundle was observed near the origin. Distally this head gives rise to a strong tendon ending just ventrally to the ventral tuberculum of the humerus, under the insertion on the mm. subscapularis and subcoraoideus. The lateral head arises by a cylindrical strong tendon from the lateral process of the coracoid, laterally to the insertion of the Lig. sternocoracoideum laterale. Between the caudal third and the middle part of the entire muscle, the tendon gives rise to a fusiform bulky belly ending with the medial head.

In the Common buzzard, the $\mathrm{CBCa}$ is a well-developed, bipinnate muscle (Fig. 2B). It arises by fleshy fibers from the Proc. craniolateralis of the sternum and a variable part of corpus coracoidei, where it is intimately associated with the insertion of the $m$. supracoracoideus. In one specimen of Buteo buteo, the coracoid insertion arose from the caudal two-thirds of both aspects of the coracoid while, in the other two, it arose from the middle third of the bone. It ended with a short tendon on the ventral tubercle of the humerus, just caudal to the distal insertion of the mm. subcoracoideus and subscapularis. Also the Common kestrel exhibited a well-developed muscle (Fig. $2 \mathrm{C})$. It arises by fleshy fibers from the incisura costalis of the sternum, from the sternal elements of the first three true ribs, from the facies muscularis of the sternum and from the caudal two-thirds of both aspects of the body of the coracoid. The sternal insertion completely covers the $m$. sternocoracoideus. The muscular belly is composed of two asymmetrical heads outlined by a slight depression. The medial head is almost fleshy while on the surface and on the lateral margin of the lateral head a fibrous component is present. The fibrous component increases distally, giving rise to the distal tendon. The entire muscle ends by a strong tendon on the ventral tubercle of the humerus, caudally to the distal insertion of the $\mathrm{mm}$. subcoracoideus and subscapularis.

\section{Musculus scapulotriceps (TrS)}

In the Grey heron, the long, well-developed TrS extends from the scapula to the ulna. It arises by a rectangular tendon from the collum scapulae. A fleshy component is present on its dorsal aspect. The scapular anchor, a robust fibrous slip inserting on the caudal margin of the muscle, was observed (Fig. 3A). It is located between the mm. scapulohumeralis caudalis and subscapularis. The fleshy component extends for the entire length of the muscle. Near the origin, just prior to the insertion of the $m$. latissimus dorsi on the humerus, another bulky fibrous slip was noted (Fig. 3A). This latter fibrous slip arises from the caudal margin of the humerus and joins the muscular belly almost at right angle. The muscle ends by a flat tendon on the proximal extremity of the ulna, near the olecranon process. It lays in close contact with the terminal tendon of the $m$. humerotriceps and the elbow joint. In the Common buzzard, the TrS exhibits a long belly that runs through the brachium adherent to the humerus. Its flat, proximal insertion is formed by poorly fibrous bundles mixed with fleshy ones. It arises from the medial aspect of the collum scapulae, dorsal to the origin of the lateral head of the $m$. subscapularis and cranially to the proximal insertion of the m. scapulohumeralis caudalis. The scapular anchor consists of a thin fibrous slip, located at the caudal margin of the proximal part of the belly and inserting on the scapula (Fig. 3B). The muscular belly, compressed dorsoventrally, exhibits a strong humeral anchor on its cranial margin (Fig. 3B). It arises from the deep surface of the muscle and it ends on the proximal extremity of the corpus humeri, just cranial to the termination of the $m$. latissimus dorsi. The distal two-thirds of the belly surface exhibited increasing fibrous bundles giving rise to the terminal tendon. This tendon runs along the sulcus scapulotricipitalis at the distal extremity of the humer$u s$ and ends on the homonymous impression of the $u \ln a$, cranially and in close contact to the termination of the m. humerotriceps. 

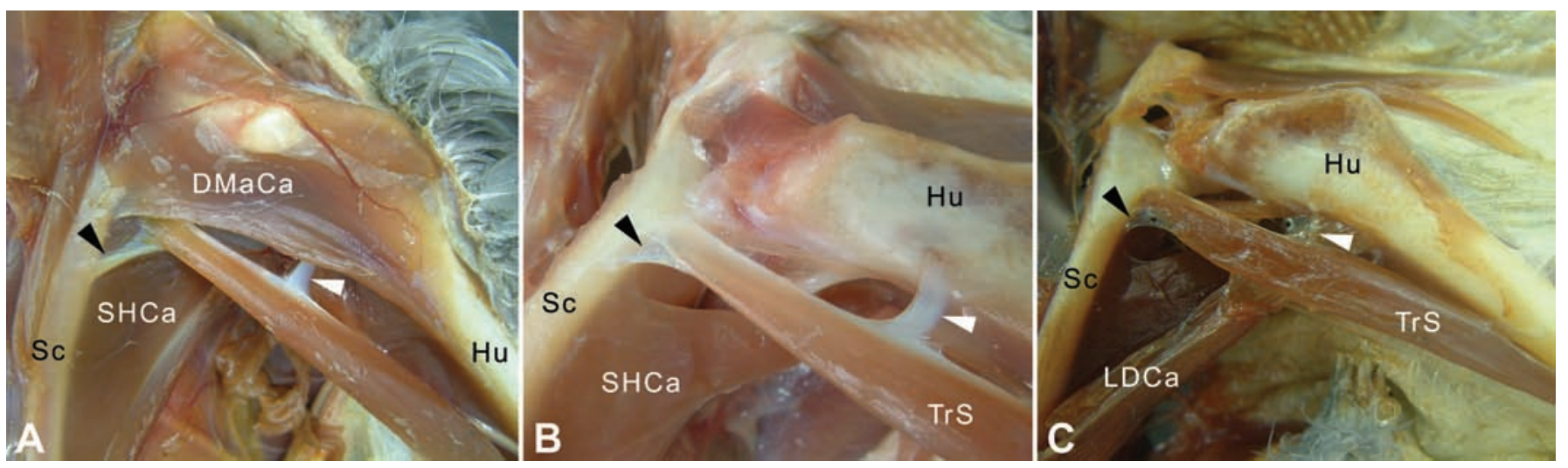

Fig. 3 - Dorsal view of the right shoulder of the Grey heron (A), Common buzzard (B), Common kestrel (C). The black arrowhead indicates the scapular anchor while the white arrowhead points at the humeral anchor. DMaCa: caudal head of the major part of $\mathrm{m}$. deltoideus; Hu: humerus; LDCa: caudal part of the m. latissimus dorsi; Sc: scapula; SHCa: m. scapulohumeralis caudalis. / Veduta dorsale della spalla destra di Airone cenerino (A), Poiana eurasiatica (B) e Gheppio comune (C). L'asterisco nero evidenzia il lacerto fibroso scapolare, mentre l'asterisco bianco indica il lacerto fibroso omerale. DMaCa: capo caudale della parte maggiore del muscolo deltoide; Hu: omero; LDCa: parte caudale del muscolo grande dorsale; Sc: scapola; SHCa: muscolo scapolo-omerale caudale.

In the Common kestrel, the TrS is a dorsoventrally flattened and well-developed muscle. It arises by fleshy fibres from a small portion of the lateral surface of the collum scapulae, dorsocranially to the insertion of the m. scapulohumeralis cranialis. A thickening of the fascia reinforces the first fourth of the cranial margin and the ventral aspect of this muscle. The caudal margin of the proximal part of the belly receives the insertion of the scapular anchor. This thin fibrous slip arises by the caudal margin of the scapula, cranially to the insertion of the $m$. scapulohumeralis caudalis. At the proximal third of the humerus, a thin humeral anchor has been observed. It is a slight fibrous slip arising from the humerus near the insertion of $m$. latissimus dorsi and inserting on the belly. The muscle then continues distally, in intimate association with the humeral shaft. At the middle of this bone, increasing fibrous bundles give rise to the terminal tendon. This tendon ends on the first fourth of the caudal margin of the body of the ulna, cranially to the insertion of the tendon of $m$. humerotriceps.

\section{Musculus extensor carpi radialis (ECR)}

In the Grey heron, a well-developed ECR is visible from both aspects of the forearm. It extends from the $h u$ merus to the carpometacarpus and is composed by a dorsal and a ventral head, both arising by tendon from the tuberculum supracondylare dorsale. The proximal tendon of the dorsal head extended up to the first third of the $r a$ dius in two subjects while it was limited to the proximal fourth in another. The fleshy belly begins just after the insertion of the terminal tendon of the caudal head of the propatagial part of the $m$. deltoideus and it extends to the distal two third of the radius. At this level, the belly gives rise to a long terminal tendon ending on the extensor process of the carpometacarpus with the tendon of the ventral part of this muscle. The ventral head arises by a short tendon that inserted slightly ventrocranially to the origin of the dorsal head. The two tendons cross each other resembling an $\mathrm{X}$. The tapered, fleshy belly of the ventral head is more developed and wider than the dorsal one. It arises near the proximal insertion and it extends just over the half of the radius. The terminal tendon of the ventral part arises proximally to the end of the fleshy component of the dorsal part. Just before the distal extremity of the radius, the two tendons converge. The resulting tendon ends on the extensor process of the carpometacarpus.

In the Common buzzard, the well-developed ECR lays in the cranial margin of the forearm and is visible from both aspects of the wing. It arises by three very short dorsoventrally overlapped cylindrical tendons from the tuberculum supracondylare dorsale. Each tendon, just after its origin, gives rise to a fleshy belly. The superficial head receives the insertions of both branches of the caudal head of the propatagial part of the $m$. deltoideus. The intermediate head is the widest and longest. The superficial and the intermediate heads, taper off at about the middle of the radius while the deep head becomes narrow at about one fourth. Each belly gives rise to three distinct tendons that run parallel along the forearm. At the distal third of the body of the radius, the three tendons converge to a single fibrous bundle. This common tendon inserts on the extensor process of the carpometacarpus. In the Common kestrel, this same muscle was visible by both aspects of the forearm. It extends from the distal extremity of the humerus to the wrist. It arises by a strong tendon from the tuberculum supracondylare dorsale. It is composed of two overlapped heads. The belly of the dorsal head arises at the first fifth of the proximal part of body of the radius occupying the second and third fifth of the same part. The proximal part of this belly receives the insertion of the caudal head of the propatagial part of the $m$. deltoideus. A fibrous component progressively strengthens the margins of the dorsal head, giving rise to a strong terminal tendon. The ventral head arises by mixed fleshy and fibrous bundles from the ventral aspect of the tuberculum supracondylare dorsale, just ventrally to the origin of the dorsal head. The fleshy belly arises near the origin and it is wider than the dorsal one. At about the middle of the body of the radius, the belly gives rise to a strong, flat terminal tendon. The tendons of both heads join along the distal portion of the cranial margin of the forearm. The resulting common tendon ends on the extensor process of the carpometacarpus. 


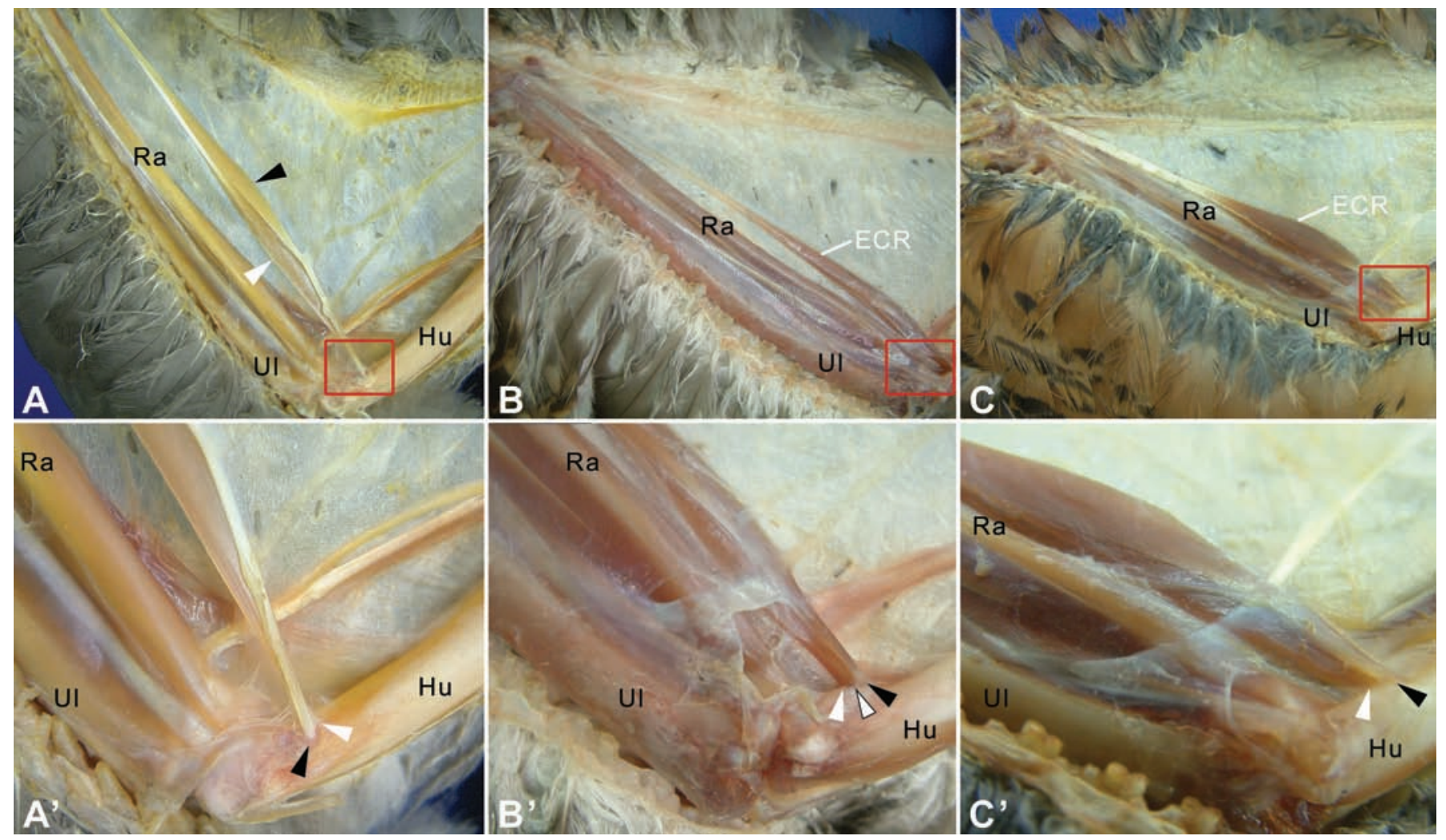

Fig. 4 - Dorsal view of the left forearm and elbow of the Grey heron (A), Common buzzard (B), Common kestrel (C). In A'-C' the origin of the proximal tendon of the ECR is showed. The black arrowhead indicates the dorsal head of the ECR, while the white arrowhead points at the ventral head. In B' the arrow indicates the intermediate head. Hu: humerus; Ra: radius; Ul: ulna. / Veduta dorsale dell'avambraccio e del gomito sinistri di Airone cenerino (A), Poiana eurasiatica (B) e Gheppio comune (C). A'-C' mostrano l'origine del tendine prossimale del muscolo estensore radiale del carpo. La testa di freccia nera indica il capo dorsale dell'estensore radiale del carpo, mentre quella bianca evidenzia il capo ventrale. In B' la freccia indica il capo intermedio. Hu: omero; Ra: radio; Ul: ulna.

\section{DISCUSSION}

\section{Musculus coracobrachialis caudalis}

In the Grey heron, the $\mathrm{CBCa}$ exhibits an unusual conformation with two "reversed" heads and a great amount of fibrous bundles. As far as the authors know, this arrangement has not been previously observed in other species (Hudson \& Lanzillotti, 1955; George \& Berger, 1966; Vanden Berge, 1970; Meyers, 1992a; Meyers, 1997; Meyers \& Mathias, 1997; Wooley, 2000; Meyers \& Stakebake, 2005; Corvidae et al., 2006; Maxwell \& Larsson, 2007). In the Rock pigeon (Columba livia G., 1789) $\mathrm{CBCa}$ is reported as a muscle having significant passive tension but short excursion. Moreover, the length-tension and force-velocity characteristics of the $\mathrm{CBCa}$ could also permit high-speed regulation of the pitch of the wing during downstroke with little neural modulation. This makes it suitable as a wing-stabilizer or muscular strut (Wooley, 2000). In particular, Wooley (2000) hypothesize that this muscle is important for the prevention of hyper-rotation during the downstroke. Also the observations of Dial et al. (1991) in the European starling (Sturnus vulgaris L., 1758) are in line with this conjecture. According to this theory, the high presence of fibrous component and the uncommon conformation of the $\mathrm{CBCa}$ in the Grey heron could be related to the high forces produced during "verti- cal landing" (near vertical descending flight mode). The large wing area and the rapid wing beats of this species during this landing behavior undoubtedly generate high friction causing rotation on the long axis of the wing and an alteration of the $\alpha$-angle (angle of attack). Therefore, the high degree of fibrous bundles and their disposition in the $\mathrm{CBCa}$ of the Grey heron could be an attempt to avoid overstretching due to this mechanical stimulation, maintaining the best $\alpha$-angle possible and maximizing landings. Moreover, also the conformation of the CBCa in the Common buzzard and in the American kestrel, which do not perform "heavy landings", is compatible with this speculation. Obviously, our conjecture should be supported by further functional studies. For example, electromyographic studies on more species should help to clarify the timing and the intensity of this muscle during wingbeat cycle. Furthermore, histochemistry or immunohistochemistry analysis could determine muscle oxidative capacity or glicolitic activity and fibres-type ("fast" or "slow").

\section{Musculus scapulotriceps}

Regarding the TrS, the major differences seen during this study were concerning the extension of the "anchors". These structures were best developed in the Grey heron, while they were less pronounced in the Common kestrel. 
An intermediate situation has been observed in the Common buzzard.

Examining the Rock pigeons in level flapping flight, Dial (1992b) suggests that the $\operatorname{TrS}$ acts as elbow jointstabilizer during the final one-half of the downstroke. The same function has been proposed during takeoff, landing and ascending (Dial, 1992a) and also the observations of Robertson \& Biewener (2012) are in line with this hypothesis. Still, Dial (1992b) believes that this muscle is not actively implicated in the extension of the wrist during level flapping flight. In another work, he suggests that this muscle could extend the elbow during descending flight (Dial, 1992a). Furthermore, Meyers (1993), in a study on the American kestrel (Falco sparverius L., 1758), hypothesized a role of this muscle in maintaining the wing extension during gliding flight. According to these studies and on the basis of our results, we may suppose that the humeral and scapular anchors could increase the belly tension during the last phase of the downstroke and the transition between downstroke and upstroke. This enhanced tension could reduce the risk of elbow joint luxation, especially during landing or takeoff. To corroborate this conjecture, a study on muscle activation and its strain should be conducted in the species examined during this study. Another interesting functional interpretation about a postural role of the $\mathrm{TrS}$ comes from a study (Meyers, 1997) on the muscles involved in the wing drying posture of the Double-crested cormorant (Phalacrocorax auritus L., 1831). Despite that the low number of tonic-fibres observed during this study does not support its postural role, Meyers (1997) suggests that the TrS could produce wing extension if the wings are held in the semi-extended position typical of the wing drying posture. Therefore, assuming the $\operatorname{TrS}$ of the Grey heron has an analogous fiber composition with respect to the findings of Meyers (1997) in the Double-crested cormorant, another speculation could be advanced. In such work the author hypothesized that the TrS could assist in maintaining the wing extension during spread-wing posture. The Grey heron has been largely observed to show the drying behavior (Clark, 1969), so both anchors, along with the few tonic-fibres eventually presents in the TrS, could passively assist in the concatenated extension of shoulder, elbow and hand during the drying behavior. Although less frequently, also the Common buzzard exhibits this behavior and the intermediate development of the anchors could be therefore correlated to this posture. Of course, our present understanding of these relationships is in its infancy and based on deductions obtained from other species. Further studies on more species should be conducted to discover the muscular activity of the triceps brachii muscle during landing and takeoff. Additionally, the study of the fiber types of this muscle should be extended to the examined species.

\section{Musculus extensor carpi radialis}

The ECR exhibits interesting findings concerning the number of heads and their disposition. The Common buzzard has, indeed, three overlapping heads instead of the typical one or two reported in literature (George \& Berger, 1966; Vanden Berge, 1970; Meyers, 1996; Meyers, 1997;
Meyers \& Mathias, 1997; Meyers \& Stakebake, 2005). Moreover, similarly to what was seen by Vanden Berge (1970) in many Ciconiiformes and by Meyers (1997) in the Double-crested cormorant, the Grey heron does not show overlapped heads and the two bellies are rather staggered. However, Meyers (1997; his Fig. 3) showed the dorsal part as being the closest to the radius while, in the Grey heron, we observe a situation analogue to Vanden Berge (1970) with the ventral head nearest to that bone. Regarding the functional role of this muscle, Nair (1954) suggested that the division of ECR is characteristic of gliding species and prevents the muscle from fatiguing by alternative belly recruitment. Thus, one belly can maintain contraction, while the other belly is in a relaxed state, allowing it to recover. Except that, to date, there is no experimental evidence that this occurs, Meyers (1997) and Meyers \& Mathias (1997) found the heads of ECR as being composed of different fiber types in the Doublecrested cormorant and in the California gull (Larus californicus L., 1854). They motivate their finding hypothesizing a postural role of some muscle also during gliding. Therefore, it is imperative to carry out a careful analysis of fiber types in ECR in the species examined (especially the Common buzzard which shows three heads) to investigate if either of the two parts of this muscle could be involved in maintaining wing position. Moreover, an electromyographic analysis of all the heads of ECR should help to clarify timing in bellies recruitments.

In conclusion, functional interpretation of bird muscles has been, and is currently, a goal for many researchers (Dial et al., 1991; Dial 1992a, 1992b; Meyers 1992a, 1992b, 1993, 1997; Meyers \& Mathias 1997; Wooley, 2000; Meyers \& Stakebake, 2005; Corvidae et al., 2006; Maxwell \& Larsson, 2007). Due to the complexity of the flight kinematics and the muscle interaction during wing beat cycle, a correct functional interpretation can be obtained only through multidisciplinary studies. However, in our opinion, an in-depth gross anatomy study should always be initially conducted, to serve as basis for further and more specific research.

\section{REFERENCES}

Baumel J.J., King A.S., Breazile J.E., Evans H.E., Vanden Berge J.C., 1993 - Handbook of avian anatomy: Nomina Anatomica Avium. Nuttal Ornithological Club, $2^{\text {nd }}$ ed. Cambridge (USA).

Brichetti P. \& Fracasso G., 2003 - Ornitologia italiana, Gavidae-Falconidae. Alberto Perdisa Editore, Bologna.

Clark G.A. Jr., 1969 - Spread-wing posture in Pelecaniformes, Ciconiiformes and Falconiformes. The Auk, 86: 136-139.

Corvidae E.L., Bierregaard R.O., Peters S.E., 2006 Comparison of wing morphology in three birds of prey: correlations with differences in flight behaviour. Journal of Morphology, 267: 612-622.

Cramp S., Simmons K.E.L., Perrins C.M., Snow D.W., 2004 - The interactive version of Birds of the Western Palearctic on DVD-ROM. Oxford University Press and Birdguides Ltd., London. 
Dial K.P., 1992a - Activity patterns of the wing muscles of the Pigeon (Columba livia) during different modes of flight. The Journal of Experimental Zoology, 262: 357-373.

Dial K.P., 1992b - Avian forelimb muscles and nonsteady flight: can birds fly without using the muscles in their wings? The Auk, 109: 874-885.

Dial K.P., Goslow G.E. Jr., Jenkins F.A. Jr., 1991 - The functional anatomy of the shoulder in the European starling (Sturnus vulgaris). Journal of Morphology, 207: 327-344.

Forsman D., 2003 - The raptors of Europe and the Middle East. Christopher Helm, London.

George J.C. \& Berger A.J., 1966 - Avian myology. Academic Press, New York and London.

Hudson G.E \& Lanzillotti P.J, 1955 - Gross anatomy of the wing muscles in the family Corvidae. American Midland Naturalist, 53:1-44.

Maxwell E.E. \& Larsson H.C.E., 2007 - Osteology and myology of the wing of the Emu (Dromaius novaehollandiae), and its bearing on the evolution of vestigial structures. Journal of Morphology, 268: 423-441.

Meyers R., 1992a - Morphology of the shoulder musculature of the American kestrel, Falco sparverius (Aves), with implications for gliding flight. Zoomorphology, 112: 91-103.

Meyers R., 1992b - The morphological basis of foldedwing posture in the American kestrel, Falco sparverius. The Anatomical Record, 232: 493-498.

Meyers R., 1993 - Gliding flight in the American kestrel (Falco sparverius): an electromyographic study. Journal of Morphology, 215: 213-224.

Meyers R., 1996 - Morphology of the antebrachial musculature of the American kestrel, Falco sparverius (Aves). Annals of Anatomy, 178: 49-60.

Meyers R., 1997 - Anatomy and histochemistry of spreadwing posture in birds 1. Wing drying posture in the Double-crested Cormorant, Phalacrocorax auritus. Journal of Morphology, 233: 67-76.

Meyers R. \& Mathias E., 1997 - Anatomy and histochemistry of spread-wing posture in birds 2. Gliding flight in the California gull, Larus californicus: a paradox of fast fibers and posture. Journal of Morphology, 233: 237-247.

Meyers R. \& Stakebake E.F., 2005 - Anatomy and histochemistry of spread-wing posture in birds 3. Immunohistochemistry of flight muscles and the "shoulder lock" in Albatrosses. Journal of Morphology, 263: 12-29.

Nair K.K., 1954 - A comparison of the muscles in the forearm of a flapping and soaring bird. Journal of Animal Morphology and Physiology, 1: 26-34.

Robertson A.M.B. \& Biewener A.A., 2012 - Muscle function during takeoff and landing flight in the Pigeon (Columba livia). The Journal of Experimental Biology, 215: 4104-4114.

Vanden Berge J.C., 1970 - A comparative study of the appendicular musculature of the order Ciconiiformes. American Midland Naturalist, 84: 289-364.

Wooley J.D., 2000 - The functional morphology of the avian flight muscle $M$. coracobrachialis posterior. Journal of Experimental Biology, 203: 1767-1776. 